\title{
Cystic Fibrosis Transmembrane Conductance Regulator
}

National Cancer Institute

\section{Source}

National Cancer Institute. Cystic Fibrosis Transmembrane Conductance Regulator. NCI

Thesaurus. Code C111927.

Cystic fibrosis transmembrane conductance regulator (1480 aa, $168 \mathrm{kDa}$ ) is encoded by the human CFT R gene. This protein is involved in chloride transport and the regulation of other ion transport pathways. 